\title{
Antidepressant-like Effects of Polygonatum humile Fisch via Serotonergic System in Mouse Model: Involvement of the Serotonin Subunit 6 Receptor
}

\author{
Dool-Ri Oh ${ }^{1}$, Yujin Kim ${ }^{1}$, Kyo-Nyeo Oh ${ }^{1}$, Yonguk Kim ${ }^{1}$ and Donghyuck Bae ${ }^{{ }^{*}}$ \\ ${ }^{1}$ Jeonnam Bioindustry Foundation, Jeonnam Institute of Natural Resources Research (JINR), \\ Jeollanamdo 59338, Republic of Korea.
}

\begin{abstract}
Authors' contributions
This work was carried out in collaboration among all authors. Authors DRO and YK designed the experiment, performed the statistical analysis, wrote the protocol and wrote the first draft of the manuscript. Author DB managed the analyses of the study and wrote the review \& editing of the manuscript. Authors KNO and YK was involved with experimentation. All authors read and approved the final manuscript.

Article Information

DOI: $10.9734 / A R R B / 2021 / v 36 i 630387$ Editor(s):

(1) Dr. Rishee K. Kalaria, Aspee Shakilam Biotechnology Institute, Navsari Agricultural University, India.

Reviewers:

(1) Frih Hacene, Badji Mokhtar University, Algeria.

(2) Farah Khan, Jamia Hamdard, India. Complete Peer review History: http://www.sdiarticle4.com/review-history/69102
\end{abstract}

Original Research Article

Received 08 April 2021

Accepted 13 June 2021

Published 19 June 2021

\begin{abstract}
Polygonatum humile Fisch is commonly called Sookjuk in Korea. The roots of $P$. humile are typically used in traditional medicine as an anti-rheumatic, demulcent, and sedative agent. The aim of this study was to evaluate the potential of the $P$. humile extracts to treat depression. Mice were administered $P$. humile water extract $(\mathrm{PH})$ and were subjected to the forced swim test (FST), tail suspension test (TST), and open-field test (OFT). The levels of brain monoamines including serotonin $(5-\mathrm{HT})$, norepinephrine, and dopamine were evaluated. In addition, the $\mathrm{PH}$ antidepressant-like effects were studied based on the regulation of $5-\mathrm{HT}$-mediated $\mathrm{Ca}^{2+}$ and extracellular signal-regulated kinase $1 / 2$ (ERK1/2) in human $1321 \mathrm{~N} 1$ cells stably expressing the 5$\mathrm{HT}$ subunit 6 receptor $\left(5-\mathrm{HT}_{6}\right)$. In FST and TST, $\mathrm{PH}(300 \mathrm{mg} / \mathrm{kg})$ significantly reduced the immobility time without changing the locomotor activity in mice. In addition, $\mathrm{PH}$ enhanced the level of 5-HT in the mice brain. The results further indicated an inhibitory activity of PH on both the $5-\mathrm{HT}_{6}$ receptor expression level and the $5-\mathrm{HT}_{6}$ receptor dependent downstream signal
\end{abstract}


pathway ERK1/2.These findings indicated antidepressant-like effects of $\mathrm{PH}$ as evidenced by decreased immobility time in mice through a 5- $\mathrm{HT}_{6}$ receptor antagonistic mechanism.

Keywords: Polygonatumhumile; fisch; antidepressant; serotonin; serotonin subunit $6\left(5-H T_{6}\right)$.

\section{INTRODUCTION}

Serotonin (5-hydroxytryptamine, 5-HT) is an important monoamine neurotransmitter found in both the central nervous system and peripheral nervous system [1]. Previous reports have demonstrated that 5 - HT plays a role in anxiety, emotion, cognition, and depression. The 5-HT receptors are divided into seven families, namely, the $5-\mathrm{HT}_{1-7}$ receptors, with a total of 14 distinct subtypes. All the 5-HT receptors are known as G-protein-coupled receptors, except for the $5-\mathrm{HT}_{3}$ receptor, which is a member of ligand-gated ion channels. In particular, 5- $\mathrm{HT}_{6}$ receptor is coupled to the Gas protein, which results in the activation of adenylyl cyclase, thereby increasing the intracellular cyclic AMP (cAMP)-protein kinase A signaling [2]. In addition, $5-\mathrm{HT}_{6}$ plays an important role in cognition, mood, psychosis, and depression $[3,4]$. Findings from recent pharmacological studies indicated that both the blockade and stimulation of $5-\mathrm{HT}_{6}$ may evoke antidepressantlike effects [5]. In addition, preclinical studies have shown that SB399885, a $5-\mathrm{HT}_{6}$ antagonist, exerts an antidepressant-like effect in the forced swimming test (FST) and tail suspension test (TST) in rats and mice [6,7]. Moreover, SB258585, which is aselective $5-\mathrm{HT}_{6}$ antagonist, is currently being developed for the treatment of depression and anxiety [8]. Thus, both antagonists and agonists of the $5-\mathrm{HT}_{6}$ receptor may be useful in treating depression.

Polygonatum humile Fisch, commonly called Sookjuk in Korea, belongs to the family Convallariaceae. The roots and rhizomes of $P$.humile have been used in traditional medicine, particularly for their anti-rheumatism, demulcent, and sedative effects [9]. In modern phytochemical studies, several components of P.humile have been identified, including polyphenols and flavonoids [10]. However, antidepressant-like effects of $P$.humile have not yet been reported.

The aim of the present study was to evaluate the effect of the blockade of the $5-\mathrm{HT}_{6}$ receptor on the antidepressant-like effects of P.humile water extract $(\mathrm{PH})$. We examined whether $\mathrm{PH}$ produced antidepressant-like effects in FST, TST, and open-field test (OFT) in mice. Additionally, the effects of $\mathrm{PH}$ on the regulation of the brain monoamines levels were examined. In addition, we used human $1321 \mathrm{~N} 1$ cells stably expressing the $5-\mathrm{HT}_{6}$ receptor to evaluate the effects of $\mathrm{PH}$ on the regulation of $5-\mathrm{HT}$-mediated $\mathrm{Ca}^{2+}$ and the extracellular signal-regulated kinase $1 / 2$ (ERK1/2), which is a key signal transduction mediator of the $5-\mathrm{HT}_{6}$ receptor.

\section{MATERIALS AND METHODS}

\subsection{Reagents}

Dulbecco's Modified Eagle's Medium (DMEM) was purchased from Hyclone Laboratories Inc. (Logan, UT, USA). Fetal bovine serum (FBS), $100 \mathrm{U} / \mathrm{mL}$ penicillin, $100 \mu \mathrm{g} / \mathrm{mL}$ streptomycin, sodium pyruvate, Lipofectamine ${ }^{T M} 2000$, pluronic F-127, and Fura-2/acetoxymethyl ester (AM) were purchased from Invitrogen Inc. (Grand Island, NY, USA). Geneticin (G-418) was purchased from Calbiochem (San Diego, CA, USA). Serotonin (5-HT), norepinephrine (NE), and dopamine (DA) enzyme-linked immunosorbent assay kits were purchased from Abnova Corp. (Taipei City, Taiwan). The primary antibodies against p44/42 MAPK (ERK1/2) and phosphorylated-p44/42 MAPK (p-ERK1/2), and the HRP-conjugated anti-rabbit IgG were purchased from Cell signaling Technology (Beverly, MA, USA).

\subsection{Preparation of the PH Extract}

The $P$. humile Fisch (specimen voucher number: JINR-PH-D-124) whole plant used in this study was collected (May 2013) in the Gangjin County (Jeollanamdo, Republic of Korea). P. humile (0.5 $\mathrm{kg}$ ) was extracted using 20 volumes of water at $100{ }^{\circ} \mathrm{C}$ for $4 \mathrm{~h}$. The extracted solution was then filtered, concentrated with an evaporator under a vacuum, and freeze-dried. The dried $\mathrm{PH}$ was stored at $4{ }^{\circ} \mathrm{C}$ to avoid compound degradation before further use in the experiments.

\subsection{Animals}

Male 6-week-old ICR mice weighing 25-29 g were purchased from the Central Lab Animal Inc. 
(Seoul, Republic of Korea). The animals were maintained at a constant room temperature of 22 $\pm 2{ }^{\circ} \mathrm{C}$ with a humidity of $50 \pm 5 \%$, and had free access to water and food under a 12:12-h light:dark cycle (lights on at 8:00 am). The animals were acclimatized to the laboratory environment for 4 days before the beginning of the experiments.

\subsection{Experimental Groups and Drug Administration}

The mice were randomly assigned to three groups $(n=5)$ based on the treatment as follows: Group I, control (vehicle); Group II, PH extract at $100 \mathrm{mg} / \mathrm{kg} / \mathrm{day}$ (PH 100); and Group III, PH extract at $300 \mathrm{mg} / \mathrm{kg} / \mathrm{day}(\mathrm{PH} 300)$. Oral administration of $\mathrm{PH}(100$ and $300 \mathrm{mg} / \mathrm{kg} /$ day $)$ was continued for 14 days. After $30 \mathrm{~min}$ of the last $\mathrm{PH}$ administration, the animals were subjected to the behavioral tests.

\subsection{Forced Swim Test (FST)}

During the FST, mice were individually placed in a Plexiglas cylinder (diameter $15 \mathrm{~cm}$ ) filled with $20 \mathrm{~cm}$ of water at $22-25^{\circ} \mathrm{C}$, and the duration of immobility, climbing, and swimming behaviors was scored during the last $5 \mathrm{~min}$ of the 6-min test. Immobility was scored when a mouse stopped struggling and remained floating motionless in the water, making only those movements necessary to keep its head above the water surface.

\subsection{Tail Suspension Test (TST)}

The immobility induced by tail suspension was carried out according to the method described by Steru et al. [11], with modification. Mice were suspended on the edge of a table $50 \mathrm{~cm}$ above the floor by an adhesive tape placed approximately $1 \mathrm{~cm}$ from the tip of the tail. The behavior of the mice was recorded at $6 \mathrm{~min}$, and the immobility time was determined by an observer. Immobility was defined as the absence of any limb or body movements. Mice were considered immobile only when they hung passively and completely motionless.

\subsection{Open-Field Test (OFT)}

The general locomotor activity was evaluated using the OFT, based on a method described previously with slight modifications [12]. The OFT apparatus consisted of a $60 \times 60 \times 20 \mathrm{~cm}$ wooden box, divided into 25 equal squares. Each mouse was gently placed in a corner of the apparatus and observed for $5 \mathrm{~min}$. A count was considered when the mouse completed a crossing from one square to the next. After each trial, the apparatus was cleaned with $70 \%$ ethanol.

\subsection{Tissue Sampling}

The mice were sacrificed immediately after the OFT. Blood was collected during decapitation. The serum was separated using refrigerated centrifugation at $3,000 \mathrm{rpm}$ and $4{ }^{\circ} \mathrm{C}$ for $20 \mathrm{~min}$, and stored at $-80{ }^{\circ} \mathrm{C}$ until further analysis. The brains were quickly removed, and the brain tissues immediately frozen in liquid nitrogen and stored at $-80^{\circ} \mathrm{C}$ until further analysis.

\subsection{Serum Biochemical Parameters}

Serum glutamic oxaloacetic transaminase (GOT), glutamic pyruvic transaminase (GPT), blood urea nitrogen (BUN), and creatinine levels were measured using the appropriate kits (DRICHEM 4000i, FUGI-FILM, Tokyo, Japan).

\subsection{Measurement of Brain Monoamines}

Quantification of monoamines was performed according to the method described previously [13], with some modifications. Briefly, the brain tissues were homogenized on ice in a 10-fold volume of an extraction buffer (PRO-PREP ${ }^{\mathrm{TM}}$ protein extraction solution, iNtRON Biotechnology, Sungnam, Korea), and incubated for $2 \mathrm{~h}$ at $4{ }^{\circ} \mathrm{C}$ with shaking. Subsequently, the lysates were centrifuged separately at 13,000 rpm for $20 \mathrm{~min}$ at $4{ }^{\circ} \mathrm{C}$. Protein contents were determined using the bicinchoninic acid protein assay reagent (Thermo Scientific, Rockford, IL) with bovine serum albumin as standard. The monoamines, 5-HT, NE, and DA were determined in the homogenates of the brain tissues as per the method described by the manufacturer (Abnova).

\subsection{Cell Culture and Transfection}

Human astrocytoma $1321 \mathrm{~N} 1$ cells, stably expressing the human $5-\mathrm{HT}_{6}$ receptor gene (cat. ES-316-CV, clone C1, PerkinElmer, Boston, MA, USA), were grown in DMEM supplemented with $10 \%$ FBS, $1 \mathrm{mM}$ sodium pyruvate, and 0.4 $\mathrm{mg} / \mathrm{mL} \mathrm{G-418} \mathrm{for} \mathrm{receptor} \mathrm{expression} \mathrm{selection,}$ and incubated at $37^{\circ} \mathrm{C}$ in a $5 \% \mathrm{CO}_{2}$ incubator. 
For transient transfection with the G-protein chimeric gene $\left(G_{q s 5}\right), 1 \times 10^{5}$ cells $/ \mathrm{mL}$ were placed on a 96-well black wall/clear bottom (BD Falcon, Franklin Lakes, NJ) and transfected with $\mathrm{G}_{\mathrm{qs} 5}$ using Lipofectamine ${ }^{\mathrm{TM}} 2000$ for $48 \mathrm{~h}$ following the manufacturer's instructions.

\subsection{Assay of 5-HT6 Receptor Activity using the High-Throughput Screening (HTS) FDSS6000 System}

The concentration of intracellular calcium $\left(\left[\mathrm{Ca}^{2+}\right]_{i}\right)$ was measured using Fura-2/AM and monitored by exciting wavelengths of $340 / 380 \mathrm{~nm}$. Briefly, $1321 \mathrm{~N} 1$ cells were washed one time with $\mathrm{N}-(2-$ hydroxyethyl)piperazine-N'-2-ethanesulfonic acid (HEPES)-buffered solution (150 mMNaCl, 5 $\mathrm{mMKCl}, 1 \mathrm{mM} \mathrm{MgCl}$, $10 \mathrm{mM}$ HEPES, $10 \mathrm{mM}$ glucose, $2 \mathrm{mM} \mathrm{CaCl}, \mathrm{pH} \mathrm{7.4)} \mathrm{and} \mathrm{loaded} \mathrm{with} 5$ $\mu \mathrm{M}$ Fura-2/AM and $0.001 \%$ pluronic $\mathrm{F}-127$ at 37 ${ }^{\circ} \mathrm{C}$ in a $5 \% \quad \mathrm{CO}_{2}$ incubator. After 60-min incubation, the cells were washed three times with the HEPES-buffered solution and maintained with a volume of $80 \mu \mathrm{L} /$ well in 96-well plates. Cells were monitored by exciting wavelengths of $340 / 380 \mathrm{~nm}$. For the antagonist experiments, cells were pre-incubated with the $\mathrm{PH}$ extract for $1 \mathrm{~min}$ before the addition of a 5-HT agonist. All data were collected and analyzed using the BD pathway 855 system and the associated AttoVision imaging software (BD Biosciences, San Jose, CA).

\subsection{Western Blot Analysis}

The $5-\mathrm{HT}_{6}$ receptor stably expressing $1321 \mathrm{~N} 1$ cells were placed in 6-well plates at a density of $1 \times 10^{6} \mathrm{cells} / \mathrm{mL}$. After $24 \mathrm{~h}$, the cells were incubated with serum-free DMEM for $2 \mathrm{~h}$, and with $\mathrm{PH}$ extract alone for $15 \mathrm{~min}$. The antagonistic effects were measured after exposure to the $\mathrm{PH}$ extract for $15 \mathrm{~min}$, and subsequent treatment with $100 \mu \mathrm{M} 5-\mathrm{HT}$ for 10 min. Subsequently, the cells were washed with cold phosphate-buffered saline and lysed using the PRO-PREP protein extraction kit (iNtRON Biotechnology). Protein contents were determined using the bicinchoninic acid protein assay reagent (Thermo Scientific) with bovine serum albumin as standard. The total proteins were incubated in boiling water for $5 \mathrm{~min}$. Samples were run at $100 \mu \mathrm{g} / \mathrm{mL}$ of protein on $10 \%$ sodium dodecyl sulfate polyacrylamide gel electrophoresis (SDS-PAGE) gels, using the Power Pac Basic electrophoresis apparatus (BioRad, Hercules, CA). Subsequently, the protein samples were transferred to polyvinylidene difluoride (PVDF) membranes $(0.45 \mathrm{~mm}$ pore size, Pall, USA). After blocking for $1 \mathrm{~h}$ at room temperature in blocking solution ( $1 \times$ Tris-buffered saline [TBS] containing $0.2 \%$ Tween 20 and $5 \%$ skim milk), the membranes were washed three times with washing solution ( $1 \times$ TBS containing $0.2 \%$ Tween 20). The membranes were incubated with the primary antibodies anti-pERK1/2 (1:1000) and anti-ERK1/2 (1:1000) overnight at $4{ }^{\circ} \mathrm{C}$. After washing five times in washing solution, the membranes were incubated in diluted HRP-conjugated anti-rabbit IgG secondary antibody (1:5000) for $1 \mathrm{~h}$ at room temperature. The detection was performed according to the manufacturer's instructions using a Chemiluminescence Detection Kit (Merck Millipore, Darmstadt, Germany).

\subsection{Statistical Analysis}

Data were presented as the mean \pm standard error of the mean (SEM). The data were statistically evaluated using the Student's t-test or one-way analysis of variance (ANOVA). Differences among groups were assessed using Duncan's multiple range tests. All statistical analyses were performed using GraphPad Prism (GraphPad Inc., San Diego, California, USA), and statistical significance was considered at $p<$ 0.05 .

\section{RESULTS AND DISCUSSION}

According to the World Health report, approximately 264 million people suffer from a mental or behavioral disorder [14]. Depression is commonly known as the mental disorder associated with feeling sad, anxious, hopeless, worthless, and guilty. Depression is also associated with several other psychiatric disorders, poor health, and increased risk of suicide [15]. Therefore, recent studies have reported that many of the available antidepressant compounds act via different mechanisms including the serotonergic, noradrenergic, and/or dopaminergic systems.

The TST and FST behavioral tests are widely used for the screening of antidepressant drugs [16]. In FST, mice are forced to swim in a restricted space from which they cannot escape, and are forced to exhibit a characteristic behavior of immobility. Immobility behavior, reflecting a state of despair, is reduced by several agents such as amphetamine and atropine, which are therapeutically effective in human depression. The TST also induces a state of despair in 
animals. This immobility is claimed to reproduce a condition similar to human depression $[11,17]$. In the present study, we confirmed the antidepressant-like effect of $\mathrm{PH}$ in both the FST and TST. Oral administration of $\mathrm{PH} \quad(300$ $\mathrm{mg} / \mathrm{kg} /$ day) significantly decreased the immobility time in FST (Fig. 1). On the other hand, administration of $\mathrm{PH}(300 \mathrm{mg} / \mathrm{kg} /$ day $)$ was associated with increased duration of swimming $(p<0.05)$ and climbing behaviors ( $p>0.05)$. In addition, $\mathrm{PH}(300 \mathrm{mg} / \mathrm{kg} /$ day) also reduced the immobility time in the TST $(p<0.05$, Fig. 2$)$. The results also indicated that the administration of $\mathrm{PH}$ at $100 \mathrm{mg} / \mathrm{kg}$ did not induce any changes in the immobility time in both the FST and TST ( $p>$ 0.05). Based on these results, we concluded that $\mathrm{PH}$ at a dose of $300 \mathrm{mg} / \mathrm{kg}$ might exert antidepressants effects. Fig. 3 depicts the effects of $\mathrm{PH}$ on the OFT results. The results indicated no alterations in the locomotor activity of mice treated with $\mathrm{PH}$ regardless of the dose used compared with the control groups.

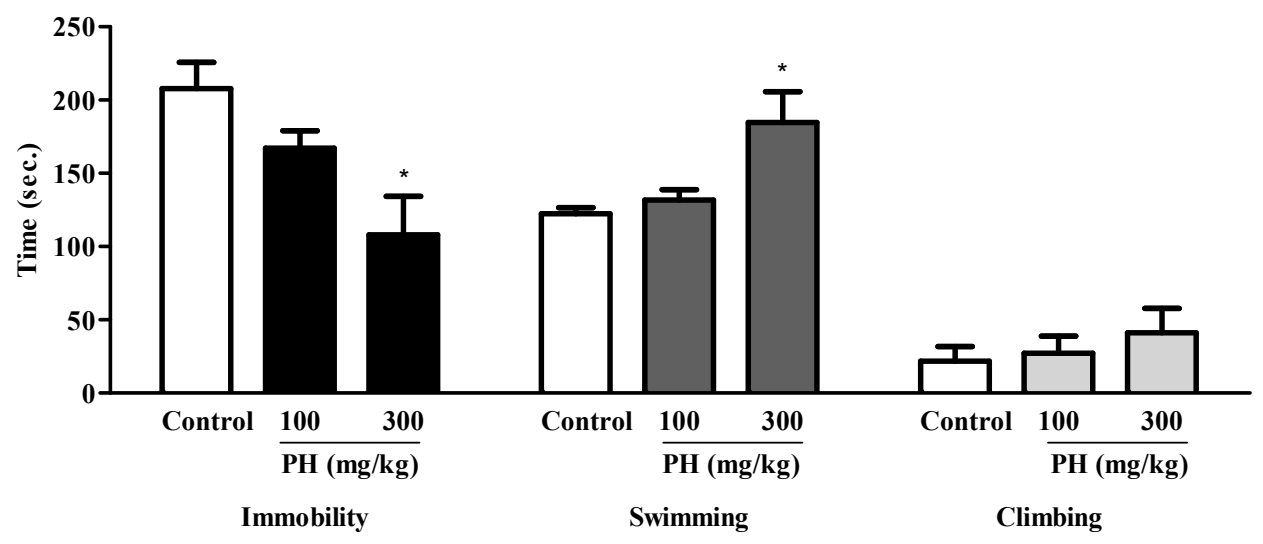

Fig. 1. Evidence of the antidepressant effect of PH in mice in the FST. Duration of immobility, swimming, and climbing behaviors recorded in the 5-min test session of FST. PH 100, $P$. humile extract $100 \mathrm{mg} / \mathrm{kg}$; PH 300, P.humile extract $300 \mathrm{mg} / \mathrm{kg}$. Values are expressed as the mean \pm standard error of the mean $(n=5) .{ }^{*} p<0.05$ compared with the respective control group

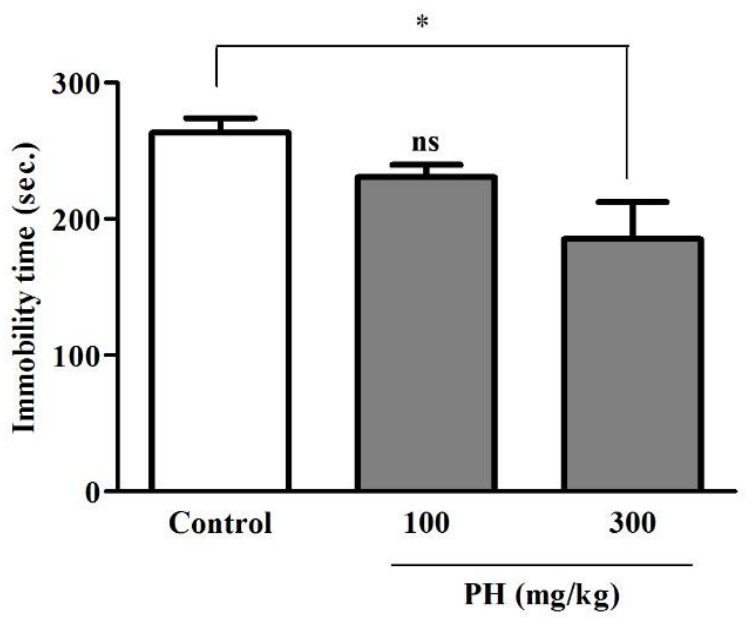

Fig. 2. Evidence of the antidepressant effect of PH in mice in the TST. Duration of immobility behaviors recorded in the 6-min test. ns, not significant; PH 100, P.humileextract $100 \mathrm{mg} / \mathrm{kg}$; PH 300, P.humile extract $300 \mathrm{mg} / \mathrm{kg}$. Values are expressed as the mean \pm standard error of the mean $(n=5)$. ${ }^{*} p<0.05$ compared with the control group 


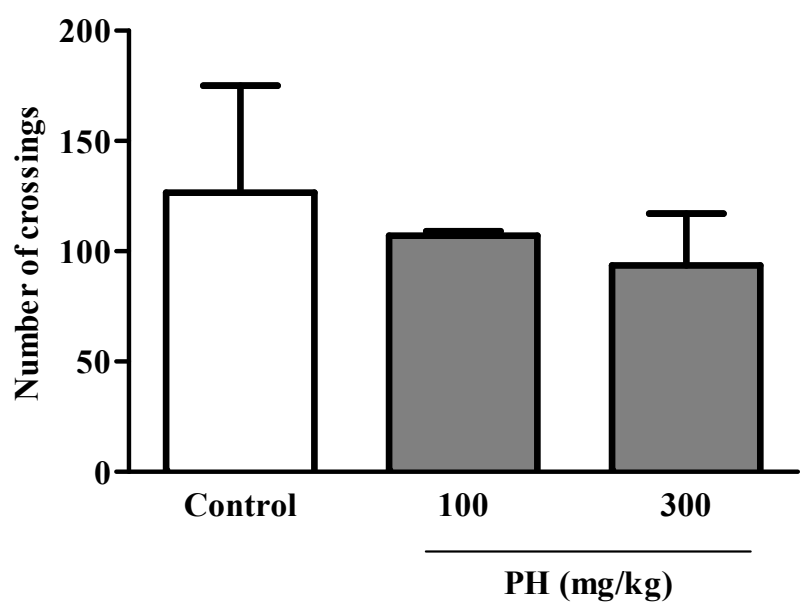

Fig. 3. Effects of PH on the mice locomotor activity (number of crossings) in the OFT. Locomotor activity was scored during 5 -min test. PH 100, P.humile extract $100 \mathrm{mg} / \mathrm{kg} ; \mathrm{PH} 300$, $P$.humile extract $300 \mathrm{mg} / \mathrm{kg}$. Values are expressed as the mean \pm standard error of the mean ( $\mathrm{n}$ = 5)

We investigated the acute oral toxicity of $\mathrm{PH}(100$ and $300 \mathrm{mg} / \mathrm{kg} /$ day) after administration in mice for 14 days. The body weight, food intake, organ weight, and serum parameters are summarized in Table 1. The body weight, food intake, and organ weight were not significantly different between the control group and the $\mathrm{PH}$ groups. Furthermore, to evaluate the potential toxic effects of ingesting $\mathrm{PH}$, serum toxicological markers indicating liver and kidney injuries were measured at the end of the experiment. The levels of GOT, GPT, creatinine, and BUN were not significantly changed in $\mathrm{PH}$-treated mice compared with the levels in the control group. These results indicated that exposure to $\mathrm{PH}$ did not cause obvious toxic effects.

Based on previous studies, the monoamines hypothesis of depression has been established whereby one of the mechanisms underlying depression includes the significant depletion of monoamines, such as 5-HT, DA, and NE [18]. In the present study, we demonstrated that daily administration of $\mathrm{PH}$ for 14 days significantly enhanced the 5-HT levels, indicating that the $\mathrm{PH}$ exerted antidepressant-like effects through the serotonergic system.As shown in Table 2, when mice were exposed to $\mathrm{PH}(300 \mathrm{mg} / \mathrm{kg} / \mathrm{day}$, oral administration) for 14 days, the 5-HT levels in the brain tissues were increased compared with the control groups $(p<0.05)$. However, the DA and NE levels did not significantly increase compared with the control groups $(p>0.05)$. These results suggested that $\mathrm{PH}$ is dependent on the serotonergic system and the elevation of $5-\mathrm{HT}$ levels in the mice brain.

The $5-\mathrm{HT}_{6}$ receptor plays an important role in the treatment of depression, cognition, and emotion. Thus, $5-\mathrm{HT}_{6}$ receptor agonists may be useful in treating depression. For example, LY-586713, a $5-\mathrm{HT}_{6}$ receptor agonist, increased the hippocampal BDNF expression, which is a cellular index of antidepressant actions [19]. In addition, the $5-\mathrm{HT}_{6}$ receptor agonist EMD 386088 produced antidepressant-like and anxiolytic effects [20-21]. The blockade of the 5$\mathrm{HT}_{6}$ receptor also elicits anxiolytic and antidepressant-like effects. Other preclinical studies have demonstrated that $5-\mathrm{HT}_{6}$ receptor antagonists such as SB399885 and SB258585 exert antidepressant-like effects in rodents [6-8]. In this study, we screened natural products to identify novel ligands of the $5-\mathrm{HT}_{6}$ receptor using the HTS FDSS6000 system (data not shown). Among those, the $\mathrm{PH}$ showed the strongest inhibitory effect on the activity of the $5-\mathrm{HT}_{6}$ receptor. The $\mathrm{PH}$ at concentrations of $1,3,10$, 30 , and $100 \mu \mathrm{g} / \mathrm{mL}$ inhibited the 5-HT-mediated $\mathrm{Ca}^{2+}$ increase in $1321 \mathrm{~N} 1$ cells stably expressing the $5-\mathrm{HT}_{6}$ receptor up to $36.69 \pm 1.99 \%, 60.50 \pm$ $0.93 \%, 61.36 \pm 0.34 \%, 73.20 \pm 0.20 \%$, and $78.11 \pm 0.49 \%$, respectively. In addition, the half maximal inhibitory concentration $\left(\mathrm{IC}_{50}\right)$ value was $2.12 \pm 5.39 \mu \mathrm{g} / \mathrm{mL}$ (Fig. 4A). We also examined the effect of SB399885, which is a selective antagonist of the $5-\mathrm{HT}_{6}$ receptor, and obtained an $\mathrm{IC}_{50}$ value of $3.46 \pm 2.27 \mu \mathrm{M}$ (Fig. 4B). As 
shown in Figs. 4C and 4D, the application of $\mathrm{PH}$ $(100 \mu \mathrm{g} / \mathrm{mL})$ and SB399885 $(10 \mu \mathrm{M})$ with 1-min pretreatment rapidly and significantly inhibited the increase of 5-HT-mediated $\mathrm{Ca}^{2+}$. These results indicated a $\mathrm{PH}$ potent antagonistic activity against the human $5-\mathrm{HT}_{6}$ receptor.

The $5-\mathrm{HT}_{6}$ receptor binds to adenylate cyclase and consequently triggers a cAMP-dependent signaling pathway. A key point signal transduction mediator in this pathway is the ERK1/2. In the present study, we examined whether the $\mathrm{PH}$ extract itself produced any effect on the ERK1/2 phosphorylation. Based on our

A

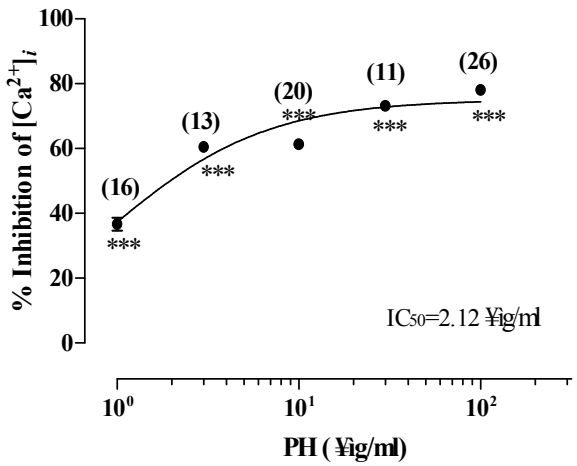

C

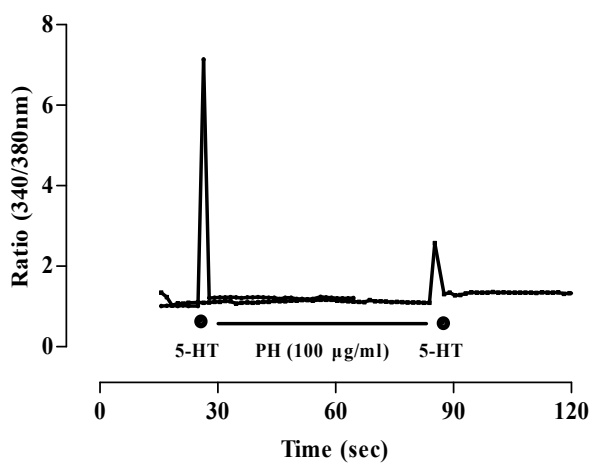

results, $\mathrm{PH}$ did not affect the EKR1/2 phosphorylation (Fig. 5A). We also assessed whether $\mathrm{PH}$ antagonizes the 5-HT-mediated ERK1/2 phosphorylation. As a standard, we used the selective $5-\mathrm{HT}_{6}$ receptor antagonist SB399885 $(30 \mu \mathrm{M})$. The administration of $\mathrm{PH}$ $(100 \mu \mathrm{g} / \mathrm{mL})$ and SB399885 $(3 \mu \mathrm{M})$ resulted in the inhibition of the 5-HT-mediated ERK1/2 phosphorylation (Figs. 5B and $5 \mathrm{C}$ ). These results indicated that the antidepressant-like effects of $\mathrm{PH}$ can be elicited by decreased behavioral immobility through the $5-\mathrm{HT}_{6}$ receptor antagonistic mechanism.

B

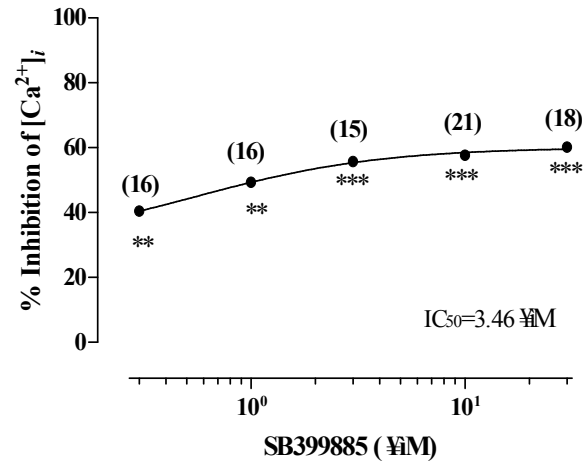

D

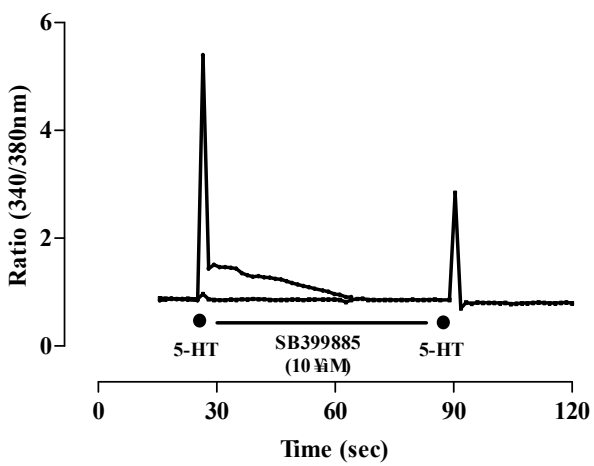

Fig. 4. Effects of $\mathrm{PH}$ and SB399885 (5- $\mathrm{HT}_{6}$ receptor antagonist, positive control) on 5-HTinduced increase of the intracellular $\mathrm{Ca}^{2+}$ concentration $\left[\mathrm{Ca}^{2+}\right]_{i}$ in human astrocytoma $1321 \mathrm{~N} 1$ cells stably expressing the $5-\mathrm{HT}_{6}$ receptor. These $1321 \mathrm{~N} 1$ cells were transfected with G-protein chimeric gene $\left(G_{q 55}\right)$ and loaded with Fura-2/AM. The percentage inhibition was calculated as $100 \times\left[\left(\right.\right.$ Ratio $_{5-\mathrm{HT}}-$ Ratio $\left._{\text {sample }}\right) /$ Ratio $\left._{5-\mathrm{HT}}\right]$. (A) Inhibition effect of the various concentrations of $\mathrm{PH}$ on 5-HT-induced $\left[\mathrm{Ca}^{2+}\right]$ increase. (B) Inhibition effect of the various concentrations of SB399885 on 5-HT-induced $\left[\mathrm{Ca}^{2+}\right]_{i}$ increase. (C) Representative tracing of the $\left[\mathrm{Ca}^{2+}\right]_{i}$ response evoked by $5-\mathrm{HT}(100 \mu \mathrm{M})$ alone or $5-\mathrm{HT}$ plus PH $(100 \mu \mathrm{g} / \mathrm{mL})$. (D) Representative tracing of the $\left[\mathrm{Ca}^{2+}\right]_{i}$ response evoked by $5-\mathrm{HT}(100 \mu \mathrm{M})$ alone or 5-HT plus SB399885 (10 $\left.\mu \mathrm{M}\right)$. PH, P.humile extract; 5-HT, serotonin $100 \mu \mathrm{M}$. Values are expressed as the mean \pm standard error of the mean $(n=5) .{ }^{* *} p<0.01$ and ${ }^{* * *} p<0.001$ compared with $5-\mathrm{HT}$ 
A

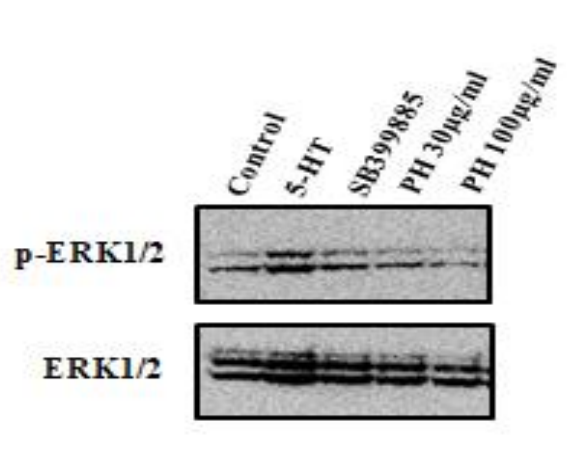

B

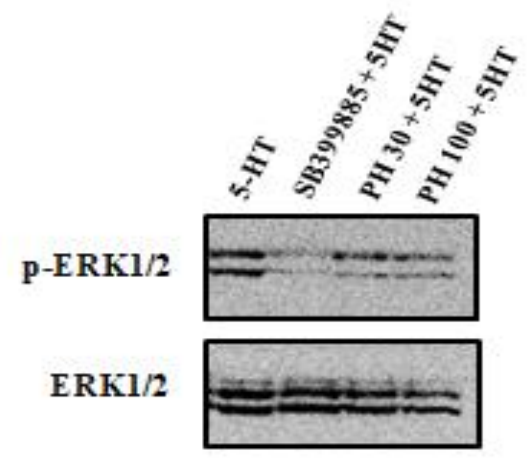

C

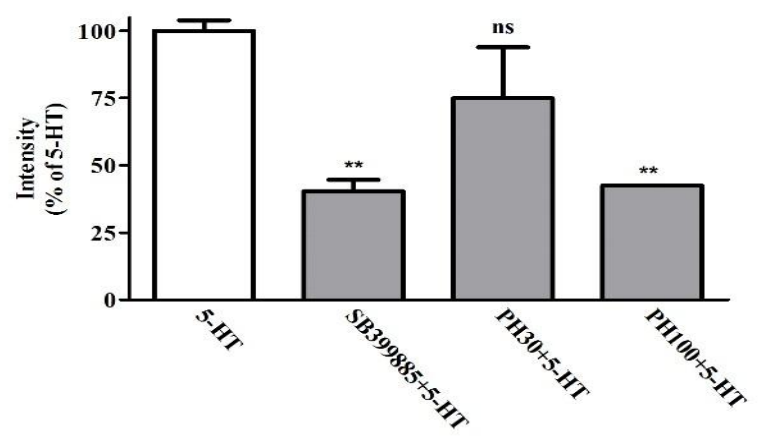

Fig. 5. Effects of PH and SB399885 (5-HT 6 receptor antagonist, positive control) on ERK1/2 phosphorylation in human astrocytoma $1321 \mathrm{~N} 1 \mathrm{cells}$ stably expressing the $5-\mathrm{HT}_{6}$ receptor. The $1321 \mathrm{~N} 1$ cells were treated with the indicated drugs for $15 \mathrm{~min}(\mathrm{~A})$. For the evaluation of the antagonistic effects, cells were pretreated with 5-HT (100 $\mu \mathrm{M})$ and incubated for 10 min after the pretreatment with the indicated drugs for $15 \mathrm{~min}$ (B). (C) Quantitative analysis of the relative ERK1/2 phosphorylation. The SB399885 was used at $3 \mu \mathrm{M}$, and $\mathrm{PH}$ was used at 30 and $100 \mu \mathrm{g} / \mathrm{mL}$. 5-HT, serotonin $100 \mu \mathrm{M}$; ns, not significant; PH 30, P.humile extract $30 \mu \mathrm{g} / \mathrm{mL}$; PH $100, P$.humile extract $100 \mu \mathrm{g} / \mathrm{mL}$. Values are expressed as the mean \pm standard error of the mean $(n=5) .{ }^{* *} p<0.01$ compared with $5-\mathrm{HT}$

Table 1. Effects of PH on the body weight, organ weight, and blood parameters in mice. Values are expressed as the mean \pm standard error of the mean $(n=5)$

\begin{tabular}{llll}
\hline & Control & PH 100 $\mathbf{~ g g / k g}$ & PH 300 $\mathbf{~ g / k g}$ \\
\hline Body weight & & & \\
Initial Body weight $(\mathrm{g})$ & $31.01 \pm 0.88$ & $31.15 \pm 0.74$ & $31.05 \pm 0.44$ \\
Final Body weight $(\mathrm{g})$ & $32.52 \pm 0.83$ & $34.91 \pm 0.73$ & $34.28 \pm 0.42$ \\
Body weight gain (g) & $1.51 \pm 1.46$ & $3.76 \pm 0.98$ & $3.23 \pm 0.75$ \\
Organ weight & & & \\
Kidney (g) & $0.59 \pm 0.03$ & $0.62 \pm 0.01$ & $0.60 \pm 0.01$ \\
Spleen (g) & $0.13 \pm 0.01$ & $0.11 \pm 0.00$ & $0.16 \pm 0.01$ \\
Liver (g) & $1.66 \pm 0.08$ & $1.98 \pm 0.05$ & $2.04 \pm 0.03$ \\
Blood parameter & & & \\
GOT (U/L) & $71.33 \pm 5.72$ & $53.00 \pm 3.51$ & $67.00 \pm 5.06$ \\
GPT (U/L) & $22.33 \pm 1.35$ & $20.25 \pm 1.30$ & $22.33 \pm 1.51$ \\
Creatinine (mg/dL) & $0.13 \pm 0.01$ & $0.13 \pm 0.01$ & $0.17 \pm 0.02$ \\
BUN (mg/dL) & $23.97 \pm 0.57$ & $23.40 \pm 0.98$ & $26.83 \pm 1.80$ \\
\hline
\end{tabular}


Table 2. Effects of PH on the monoamine neurotransmitter levels in the mouse brain.Values are expressed as the mean \pm standard error of the mean $(n=5) .5-H T$, serotonin; DA, dopamine; $\mathrm{NE}$, norepinephrine. ${ }^{*} p<0.05$ compared with the control group

\begin{tabular}{llll}
\hline Monoamines & Control & PH $\mathbf{1 0 0} \mathbf{~ m g} / \mathbf{k g}$ & PH 300 $\mathbf{~ m g} / \mathbf{k g}$ \\
\cline { 1 - 2 }$(\mathrm{ng} / \mathrm{mg}$ protein) & & & \\
$5-\mathrm{HT}$ & $2,530.16 \pm 3.25$ & $2,713.48 \pm 36.21$ & $3,064.28 \pm 30.84$ \\
$\mathrm{DA}$ & $260.85 \pm 4.03$ & $276.01 \pm 9.97$ & $298.46 \pm 8.54$ \\
$\mathrm{NE}$ & $65.66 \pm 1.05$ & $68.15 \pm 2.25$ & $74.65 \pm 1.67$ \\
\hline
\end{tabular}

Polyphenols and flavonoids have been identified in $\mathrm{PH}$ [10]; in particular, naringenin, curcumin, ellagic acid, rutin, quercetin, apigenin, and resveratrol showed possible antidepressant and anxiolytic actions [22]. However, the underlying mechanisms of these $\mathrm{PH}$ antidepressant effects remain unknown. Further studies will be required in order to define the functional compounds that regulate the antidepressant-like effects of $\mathrm{PH}$ through the $5-\mathrm{HT}_{6}$ receptor blockade.

\section{CONCLUSION}

The present findings indicated that $\mathrm{PH}$, which is a new herbal medication, can regulate depression through the action of the $5-\mathrm{HT}_{6}$ receptor antagonistic mechanism.

\section{ETHICAL APPROVAL}

All experiments were approved by the Institutional Animal Care and Use Committee (IACUC) at Jeonnam Institute of Natural Resources Research (approval no. JINR-19062019). All animal experiments were conducted in accordance with the IACUC guidelines.

\section{ACKNOWLEDGEMENTS}

This research had no funding support.

\section{COMPETING INTERESTS}

Authors have declared that no competing interests exist.

\section{REFERENCES}

1. Yohn CN, Gergues MM, Samuels BA.The role of 5-HTreceptors in depression. Molecular Brain. 2017;10(1):1-12.

2. Ferrero $H$, Solas $M$, Francis $P T$, Ramirez MJ. Serotonin 5- $\mathrm{HT}_{6}$ receptor antagonists in Alzheimer's disease: therapeutic rationale and current development status.CNS Drugs. 2017;31(1):19-32.
3. Sulbha C, Radhakishnan M, Baldev G, AnkurJ, Shvetank B. Serotonin 5- $\mathrm{HT}_{6}$ receptor: a potential target for cognition. In Res J Pharm. 2010;1(1):7-18.

4. Wesolowska A. Potential role of the $5-\mathrm{HT}_{6}$ receptor in depression and anxiety: an overview of preclinical data. Pharmacol Rep. 2010;62(4):564-577.

5. Yun HM, Rhim H. The serotonin-6 receptor as a novel therapeutic target. ExpNeurobiol. 2011;20(4):159-168.

6. Wesolowska A. Study into a possible mechanism responsible for the antidepressant-like activity of the selective $5-\mathrm{HT}_{6}$ receptor antagonist SB-399885 in rats. Pharmacol Rep. 2007;59:664-671.

7. Wesolowska A, Nikiforuk A. Effects of the brain-penetrant and selective $5-\mathrm{HT}_{6}$ receptor antagonist SB-399885 in animal models of anxiety and depression. Neuropharmacology. 2007;52(5):12741283.

8. Wesolowska A, Nikiforuk A, Stachowicz K. Anxiolytic-like and antidepressant-like effects produced by the selective $5-\mathrm{HT}_{6}$ receptor antagonist SB-258585 after intrahippocampal administration to rats. BehavPharmacol. 2007;18(5-6):439-446.

9. World Health Organization (WHO). Medicinal Plants of China: A selection of 150 commonly used species. Manila: WHO Regional Office for the Western Pacific; 1989.

Available:https://apps.who.int/iris/handle/1 0665/207581

10. Kim EJ, Choi JY, Yu M, Kim MY, Lee S, Lee $\mathrm{BH}$. Total polyphenols, total flavonoid contents, and antioxidant activity of Korean natural and medicinal plants. Korean $\mathrm{J}$ FoodSci Thechnol. 2012;44(3):337-342.

11. Steru L, Chermat R, Thierry B, Simon P. The tail suspension test: a new method for screening antidepressants in mice. Psychopharmacology (Berl). 1985;85(3): 367-370.

12. Xu Q, Yi LT, Pan Y, Wang X, Li YC, et al. Antidepressant-like effects of the mixture 
of honokiol and magnolol from the barks of Magnolia officinalis in stressed rodents. Prog Neuropsychopharmacol Biol Psychiatry. 2008;32(3):715-725.

13. Lee WK, Kim TI, Park SK, Park HK, Hong JT. Anxiolytic effect of a combination of green tea extract and L-theanine. Laboratory Animal Research. 2010;26:6368.

14. GBD. Disease and Injury Incidence and Prevalence Collaborators. Global, regional, and national incidence, prevalence, and years lived with disability for 354 diseases and injuries for 195 countries and territories, 1990-2017: A systematic analysis for the Global Burden of Disease Study 2017. Global Health Metrics. 2018;392(10159):1789-1858.

15. Mullins $\mathrm{N}$, Bigdeli TB, Børglum AD, Coleman JRI, Demontis D, Mehta D, Power RA, RipkeS, Stahl EA, , Anjorin A, et al. GWAS of Suicide Attempt in Psychiatric Disorders and Association With Major Depression Polygenic Risk Scores.Am J Psychiatry. 2019;176(8):651660.

16. Pollak DD, Rey CE, Monje FJ. Rodent models in depression research: Classical strategies and new directions. Annals Med. 2010;42(4):252-264.
17. Backer M, Pinhasov A, Ornoy A. Animal models of depression: What can they teach us about the human disease? Diagnostics, 2021;11(1):123-154.

18. Perez-Caballero L, Torres-Sanchez S, Romero-López-Alberca C, González-SaizF, MicoJA, Berrocoso E. Monoaminergic system and depression. Cell Tissue Res. 2019;377(1):107-113.

19. De Foubert G, Khundakar AA, Zetterstrom TS.Effects of repeated 5-HT6 receptor stimulation on BDNF gene expression and cell survival. Neurosci Lett. 2013;553:211215.

20. Artigas F. Serotonin receptors involved in antidepressanteffects. Pharmacol Ther. 2013;137(1):119-131.

21. Jastrzębska-Więsek $M$, Siwek $A$, Partyka A, Kołaczkowski M, Walczak M, Smolik M, Latacz G, Kieć-Kononowicz K, Wesołowska A. Study on the effect of EMD386088, a 5-HT6 receptor partial agonist, in enhancing the anti-immobility action of some antidepressants in rats. Naunyn Schmiedebergs Arch Pharmacol. 2018;391(1):37-49.

22. Pathak L, Agrawal $Y$, Dhir A. Natural polyphenols in the management of major depression. Expert Opinlnvestig Drugs. 2013;22(7):863-880.

(c) 2021 Oh et al.; This is an Open Access article distributed under the terms of the Creative Commons Attribution License (http://creativecommons.org/licenses/by/4.0), which permits unrestricted use, distribution, and reproduction in any medium, provided the original work is properly cited. http://www.sdiarticle4.com/review-history/69102 